\title{
Employability in India - Challenges and Solutions
}

\author{
Sathiya Priya $\mathbf{J}^{1}$, Fathima $\mathbf{Z}^{2}$, Sridurgadevi $\mathrm{S}^{3}$ \\ UG Scholar, Department of Electronics and Communication Engineering, V.R.S College of Engineering and \\ Technology, Arasur, Villupuram, Tamil Nadu, India ${ }^{1,2}$ \\ Assistant Professor, Department of Electronics and Communication Engineering, V.R.S College of Engineering and \\ Technology, Arasur, Villupuram District, Tamil Nadu, India ${ }^{3}$
}

\begin{abstract}
Over 100 years. Employability is an emerged concept in unemployment and labour markets. Part of the problem of youth employability is the relevance of acquired knowledge, skills and educational and training qualifications to current labour market opportunities. This paper focuses the concept of employability and skills needed to become a globally recognized employee. The perception of Employers and employees towards employability skills required for Entry level engineering graduates in multinational software companies is examined. An approach of accreditation towards higher education is explained and highlighted the importance of accreditation in Indian Institutions. The development skills available in India which are needed to enhance the employability in global market are projected. Overall this paper paves a way for an Indian employee to work in global market.
\end{abstract}

Keywords: Employability, engineering graduates, employers, perception, accreditation and global market.

\section{INTRODUCTION}

Globalization places a high premium on education and skills. Globalization has intensified international competition between companies and countries in products and services, their design, distribution and cost. As a consequence, it has placed a premium on developing a high-quality labour force. ${ }^{[1]}$

Employability can be defined as "doing value creating work, getting paid for it - and learning at the same time, enhancing the ability to get work in the future. Employability is a management philosophy, developed by late Professor Sumantra Ghoshal and others, which recognizes that employment and market performance stem from the initiative, creativity and competencies of all employees, and not just from the wisdom of senior management. For employers, it involves creating a working environment that can provide opportunities for personal and professional growth, within a management environment where it is understood that talented, growing people mean talented, growing organizations. For many employees, the new contract would involve movement towards a greater commitment to continuous learning and development, and towards an acceptance that, in a climate of constant change and uncertainty, the will to develop is the only hedge against a changing job market.

1.1 Employability Skills

Employability skills have been defined as "A set of achievements, understandings and personal attributes that make individuals more likely to gain employment and to be successful in their chosen occupations". You may also see these skills referred to as transferable skills or personal skills. In the context of your career planning and development, they are called career management skills.

1.1.1Factors that help to make people employable include

- Knowledge and abilities relating to a particular job.
- The ability to identify suitable job opportunities.

- Self-presentation (on applications and at interviews)

- External factors such as the job market and personal circumstances.

1.2 Expectation of Skills from Graduates

Employers look for a range of skills in graduate applicants, many of which are common to a number of different career areas. Those most frequently mentioned are communication, team working, leadership, initiative, problem-solving, flexibility and enthusiasm.

Many skills overlap with one another. Leadership, for example, encompasses a number of other skills including cooperating with other planning and organizing, making decisions and verbal communication. Verbal communication itself involves various means of communication, some of which you may find easier than others - talking over the phone, making a presentation to a group or explaining something to a person with a more limited understanding of the topic. By improving one skill, you may also improve in a number of others.

Among the most important generic skills identified by various researchers exploring the employers and graduates views are: analytical/research skills computer/ technology skills interpersonal/teamwork skills, communication skills both verbal and written leadership/problem-solving skills creative/innovative skills self-management lifelong learning emotional intelligence.

\section{GLOBALIZATION EFFECTS ON INDIA}

India has also promoted higher education through the propagation of universities; however, funding to elementary education has declined. Sixty-three million children age 6 to 14 are out of school due the reduced education budget. The Indian government has invested a 
lot in promoting higher education in the country, but more progress could be made with the help of private interests. The private sector has more than enough financial power to increase the literacy rate and access to higher education. It can be done through private universities and learning centers.

In addition, global universities might be established in India so the global perspective can be fixed into the curriculum. Four aspects of global education that universities in India might focus on are a global curriculum, global faculty, global degrees, and global interaction. These aspects would not only help promote higher education, but would help prepare India for the growing global competition that globalization is creating.

\subsection{NASSCOM report on employability in India}

The AICTE, Chairman SS Mantha came down on the surveys done by the NASSCOM and other firms. Recently National Association of Software \& Services Companies (NASSCOM) and other private firms surveyed that only $25 \%$ graduates in India are employable. ${ }^{[4]}$ SS Mantha questioned the vary basis of these surveys, stating those were limited to very few people.SS Mantha said, "Around 1.5 million engineering degree and 1 million diploma seats are present in India. In which, every year 1 million graduates come out for jobs and higher studies. If we considered survey figures, then about 7.5 lakh engineers should be rendered unemployed. If cumulative average of five years is taken into account then it will have 35 lakh unemployed engineers,"

He said that, this situation would have led to civil war but the reality was in complete contrast. This is certainly not the case and maximum of them are getting jobs. The only reason is they are underemployed and not getting the deserving salary. These surveys were conducted without any logical background and thus create confusion. The AICTE chief states that NASSCOM had taken database of candidates coming for the interviews in 500 IT companies and arrived at these conclusions. "But India is vast country and these findings are far from reality," he said, this is for the first time that any apex body had come out openly against NASSCOM survey.

Mantha rechecked AICTE's stand of improving quality education, stating that it had started an e-governance project under by collecting date from all the states. He admitted that no survey was conducted on the actual number of jobs in engineering and other professional sectors in India and their demand-supply gap. "For an important branch like mining, having tremendous demand in the market, there are only 654 seats in the entire country.

The former pro-Vice Chancellor of SNDT University admitted that there were concerns on the quality of engineering entrance examinations conducted by the states. MHT-CET entrance conducted by the Maharashtra government for admission to engineering, medical, pharmacy and veterinary courses has qualifying marks of just 1/200.He rediculed the present school system, terming it as "redundant" as marks of Class 10 and 12 were not considered from the admission to professional courses. "The students have completely lost the focus on the board examination and started ignoring it.
We therefore have decided to give $40 \%$ weight age to the class 12 board examination and $60 \%$ to JEE exam so that students should focus equally on both."

\subsection{Employability Skills of Graduates in India}

India is one of the emerging markets in the world. India's change from an agrarian economy to an industrialized economy is lagging due to the shortage of skilled labour. (The skill development landscape in India and implementing quality skill training, August 2010). Although the country has enough potential to deliver to the needs of the global talent market, the strong employability challenge of the graduates; especially engineering graduates became the bottleneck for India's growth perceptive.

Even in India, which produces 400,000 engineers annually, corporations are finding it increasingly difficult to find the qualified workers they require. (Replacement migration, 2009).India's National Association of Software Services Companies estimates a potential shortfall of 500,000 technology professionals by 2010 (Talent shortage survey, 2005).There were several studies conducted in India to know the employability skills.. It is found that $75 \%$ of the Indian graduates are unemployable. (Talent shortage survey, 2005).There was an argument that this study doesn't give a clear picture of Indian graduates and it is outdated. But the recent study conducted by World Bank (2011) points out that $64 \%$ of the employers say they are only somewhat satisfied with the performance of the engineering graduates in India (Andreas Blom, 2011). Globally about $34 \%$ of the employers (Talent shortage survey, 2005) find it difficult to fill the talent gap and in India $67 \%$ of the employers find it difficult to find right talent in India(from both arts and science graduates).These results points out the need for proper awareness and training among the graduates to enhance their skills.

\section{INTERNATIONAL DEVELOPMENT}

International development or global is a wide concept concerning level of development on an international scale. It is the basis for international classifications such as developed country, developing country and least developed country. There are however many schools of thought and conventions regarding, which are the exact features constituting development of a country.

Historically it has been largely synonymous with economic development. Recently it is also often used in a holistic and multi-disciplinary context of human development as well as other concepts like competitiveness, quality of life or subjective wellbeing. International development is different from simple development in that it is specifically composed of institutions and policies that arose after the Second World War. These institutions focus on alleviating poverty and improving living conditions in previously colonised countries.

\subsection{Accreditation context}

Accreditation is another widely used method in European quality assurance. It is especially common in the associated countries, where this method has been a 
traditional way of assuring the quality of higher education. Moreover, countries such as Germany, Norway, and the Netherlands have since the completion of the survey decided that this should be the main type of quality assurance of higher education.

Accreditation is defined in many ways. Three examples are: - "Accreditation is a formal, published statement regarding the quality of an institution or a programme, following a cyclical evaluation based on agreed standards".

"Accreditation is a process of external quality review used by higher education to scrutinize colleges, universities, and higher education programmes for quality assurance and quality improvement".

"Accreditation is the award of a status. Accreditation as a process is generally based on the application of predefined standards. It is primarily an outcome of evaluation". Considering the individual responsibility of the institutions of higher education on the one hand, and the responsibility of the overall national quality assurance systems on the other hand, the Berlin Declaration of 19 September, 2003 lists both evaluation and accreditation as important tools for quality assurance. It has been agreed "that by 2005, national quality assurance systems should include the following:

- Evaluation of programmes or institutions, including internal assessment, external review,

- Participation of students and the publication of results,

- A system of accreditation, certification or comparable procedures.

\subsection{Accreditation procedures}

Accreditation procedures contribute to the continued quality development of the accredited academic unit: Institutions receive advice about quality improvement throughout the accreditation process, which may extend beyond the "yes/no" decision itself. The present concept of accreditation in the area of higher education serves to assure and develop quality; it can focus on institutions, constituent parts and study programmes, in order to:

- ensure or facilitate recognition of "credits" and university degrees in an academic context, such as, for example, when changing from one institution of higher education to another, in order to promote mobility,

- inform current and prospective students on the value of certain study programmes (consumer protection),

- allow employers to check the value and status of qualifications,

- Give institutions of higher education the opportunity to demonstrate appropriate allocation and use of public funds.

\subsection{Accreditation in higher education}

Accreditation is a collegial process of self-review and peer review for improvement of academic quality and public accountability of institutions and programs.

This quality review process occurs on a periodic basis, usually every three to 10 years. Typically, it involves three major activities:

- A self-evaluation by an institution or program using the standards or criteria of an accrediting organization
- A peer review of an institution or program to gather evidence of quality.

- A decision or judgment by an accrediting organization to accredit, accredit with conditions, or not accredit an institution/program.

Accreditation is an extraordinary element of quality. These may be part of the accreditation report, although they don't have any influence on the accreditation outcome: it is an extra.

They may be for instance:

-Pedagogical system (for instance Problem Based Learning)

- Internationalization (composition of staff and students)

- Excellent relation with the work field and

- Excellent quality.

\section{ACCREDITATION-INDIAN CONTEXT}

Accreditation is an integral part of the higher education institutions. The two accreditations that higher education institutes in India are required to have are accreditation to regulatory bodies, and accreditation to professional associations. Accreditation to regulatory bodies, such as AICTE, NAAC and UGC ensures that academic institutes are developing and maintaining certain level of standards in terms of infrastructure, faculty, pedagogy, etc. Without accreditation, institutes may go for sub-standard measures at students' cost. Accreditation to professional associations such as the Bar Council of India, Energy Institute UK, Council of Architects, Indian Institute of Town Planners, etc. validates academic rigor required for the profession, industry acceptability of qualification, and reinforces employability of graduates. ${ }^{[7]}$

\subsection{Accreditation in Indian education}

The Indian higher education system has inherited many regulatory mechanisms from the British legacy of higher education. While the regulatory mechanisms have ensured satisfactory functioning of the system with unprecedented quantitative expansion, raising the standards of higher education could not be achieved. With 259 universitylevel institutions, more than 10,750 colleges, 8 million students, and 400,000 teachers, India has one of the world's largest higher education systems.

While the numbers may look impressive, they cover only 6 percent of the relevant age group, and 88 percent of student enrollments are in undergraduate education. Ensuring the quality of education provided to this small percentage is vital to the success of the nation. The situation gets further complicated with colleges taking a lead in undergraduate education and the affiliating system that loosely connects the colleges and universities. Most Indian universities are of the affiliating type where the affiliating university legislates on courses of study, holds examinations centrally on common syllabi for its affiliates, and awards degrees to successful candidates.

With the larger affiliating universities having more than 400 affiliated colleges, the academic leadership provided to affiliates has come under severe criticism. Many of the preconditions that ensured educational quality, while granting affiliation to colleges, have now been either ignored or soft-pedaled, with the result that many 
substandard institutions have come into existence, with the possibility of many more to come. The growth of private initiatives has also increased the concern for quality. To increase access to education, India has encouraged private initiatives. The Government-run colleges are few, and privately managed trusts or societies have founded the greater number of colleges - about 70 percent of the total. Most of the private colleges established before the 1980s get more than 95 percent of their financial support from the state government, and they are called grant-in-aid colleges. With limited resources, government could not extend financial support to the private initiatives established after the 1980s. These colleges run on student fees, and they are known as self-financing colleges. Though self-financing, they have to comply with the rules of the government and the affiliating university. The growth in the number of self-financing colleges adds to the pressure on the affiliating universities. The direct public expenditure on the public-funded institutions, the high fee structure of the self-financing colleges, and the substandard facilities available in some of these institutions have raised the question of "value for money" and hence the need for an effective mechanism for quality assurance. Accreditation by an autonomous body was seen as an appropriate strategy for quality assurance.

Consequently, as a part of its responsibility for the maintenance and promotion of standards of education, the University Grants Commission (UGC) established the National Assessment and Accreditation Council (NAAC) in 1994.

The methodology is in line with the international trend-a combination of self evaluations and peer review based on predetermined criteria for assessment. It is a voluntary process, and the final outcome of the process is an overall grade on a five point scale and a detailed assessment report, valid for a period of five years. Both the grade and the report are made public. Although the NAAC has the provision to do both institutional and departmental assessment, during the first cycle, institutional accreditation has been promoted consciously. By the end of 2001, the NAAC has 25 assessed around 200 institutions of higher education, and it recently conducted a study to analyze the impact of accreditation on the institutions of higher education.

India has 723 universities, which include many institutions of national importance, 37,204 colleges and 11,356 professional schools offering diplomas. Overall, about 28.6 million students are pursuing higher education, according to an official data. Less than 25 percent of these institutions are accredited.

There is a grave need for accreditation process to keep pace with higher education institutions in the world. It will also help in keeping abreast of changes in higher education. Several factors hinder the global employability of professionals. For instance, deep-rooted and highly contextual differences in educational framework of countries continue to be major impediments in credentialing engineers and management professionals. Gregory Prastacos, Dean, Stevens Institute of Technology, USA, says, "Accreditation guarantees the quality of education provided is according to the standards agreed upon, from content and relevance, to pedagogy and connections to industry. It's a quality guarantee not only to students and parents, but also to employers, who can be assured of the quality of education, a job candidate has received before employment."

4.2 Developing Employability Skills in India

Skill development can be viewed as an instrument to improve the effectiveness and contribution of labour to the overall production. Skill development can also be seen as a means to empower the individual and improve his/her employability. Skill development in India draws its attention from the changing demographic profile. India has a unique 20-25years window of opportunity known as 'demographic dividend'. Global economy is expected face a skilled manpower shortage to the extent of around 56 million by 2020 . Hence, skill development in India is a big challenge although, skill development has several challenges before it.

\subsubsection{Need for Skill Development}

Employability skills are those skills necessary for getting, keeping and being successful in a job. They are the skills and attitudes that enable employees to get along with their colleagues, to make critical decisions, solve problems, develop respect and ultimately become strong ambassadors for the organization. Employability or 'soft skills' are the foundation of your career building blocks and they are frequently referenced in the media as lacking in school-leavers, graduates and those already in employment. ${ }^{[2]}$

Organizations spend a lot of time and money training staff, not in job specific areas but in general and basic skills.

In the backdrop of India's employment scenario it becomes imperative to formulate a National Policy on Skill Development and initiate a Program of Action.

4.3 National Skill Development Policy and Government's Coordinated Action on Skill Development

As India is a growing knowledge society which also has maximum population in the age group of 20-25years, it has created a Coordinated Action on Skill Development. National Council (2) National Skill Development Coordination Board (NSDCB), and (3) National Skill Development Corporation (NSDC). P.M.'s National Council on Skill development has formed a policy in the form of "core principles" and has given a vision to create 500 million skilled people by 2022 . $^{[2]}$

4.3.1 Objectives of National Skill Development Policy There is an urgent need of Partnership between the Government and Universities' departments of Life Long Learning and Extension to achieve the goal of National Policy of Skill Development and some objectives of National Skill Development Policy includes:

- Create opportunities for all to acquire skill throughout life, especially for youth, women, and disadvantaged groups.

- Promote commitment by all stakeholders to own skill development initiatives.

- Develop a high quality skilled workforce/entrepreneur relevant to current and emerging market needs. 
- Enable the establishment of flexible delivery mechanisms that respond to the characteristics of a wide range of needs of stake holder.

- Enable effective coordination between different ministries, the Centre, and the State and public and private providers.

\subsubsection{Scope of the National Skill Development Policy}

India has a Demographic Dividend which can serve not only our nation but the need of the global economy provided the youth is equipped with modern skills. National Policy on Skill Development is designed to serve the need. ${ }^{[3]}$ There are certain challenges before the Government in the implementation of the Policy, such as in disseminating information about the availability of programs, inadequate vocational training system, need of institution to carry out impact evaluation studies etc. Universities' departments of Life Long Learning and Extension like their any other departments are rich source of human resource.

The departments can work for disseminating information about the Program, can run vocational courses, can carry out impact assessment research, and can suggest measures to make the plan of action more viable. Scope of the policy includes,

- Institution based Skill development including ITIs/ITCs/Vocational /Technical Colleges/ Poly techniques/ Professional Colleges etc.

- Learning initiative of Sectoral Skill development organized by different ministries/departments.

- Formal \& Informal apprenticeships and other types of training by enterprises.

- Training for self employment/entrepreneurial development

- Adult learning.

\section{CONCLUSION}

The concept of employability provides a better scope for skilled professionals and graduates in global market. The paper implies an immediate need for gaining the employability skills among the Indian graduates to shine in the global market. It is essential to provide well qualified and assured higher education system to raise their bar to attain jobs in the global talent market. It is very clearly shown the importance of accreditation and its procedures that are followed in higher education in India. Enhancing the employability skills through accreditation and some development skills will motivate the Indian graduates to produce their best and to achieve their goals in global labour market.

\section{REFERENCES}

[1] Ghose, Ajit K., Nomaan Majid and Christoph Ernst (2008), the Global Employment Challenge, International Labour Office, Geneva and Academic Foundation, New Delhi.

[2] IAMR, Planning Commission, Govt. of India (2010), the Challenges Facing Skill Development in India: An Issue Paper.

[3] ICRA Management Consulting Services Limited August, 2010 The Skill Development Landscape in India and Implementing Quality Skills Training.

[4] Ministry of Labour and Employment, Government of India (2008), Selected Labour and Employment Statistics, Directorate General of Employment \& Training, Government of India, New Delhi.
[5] Andreas Blom, H. S. (2011). "Employability and Skill Set of Newly graduated Engieers in India". World Bank..

[6] Atkins, M. J. (1999). "Oven ready and self-blasting:taking stock of employability skills. Teaching in Higher education, Vol 4 No 2, pages $267-78$.

[7] Azami zaharim, e. (2009). "Employers perception towards engineering employability skills in Asia. WSEAS Transactions on advances in Engineering education, issue 6, vol.3, pp306-315.

[8] Busse, R. (1992). "The new basics:-today's employers want three R and so much more". Vocational Educational Journal, Vol.67, No. 5,PP 24-25.

[9] Chitra.R (2013). "Employability Skills -A Study on the Perception of the Engineering Students and their Prospective Employers". "Global Journal of Management and Business Studies. ISSN 22489878 Volume 3, Number 5. 